\title{
Reproductive efficiency and serum progesterone concentration on dairy cattle based on blood urea nitrogen (BUN) concentrations
}

\author{
K.Y. Putri ${ }^{1}$, P. Srianto ${ }^{2}$, T.D. Lestari ${ }^{2}$, S. Utama ${ }^{2}$, Wurlina ${ }^{2}$ and I. Mustofa ${ }^{2} *$ \\ ${ }^{1}$ Postgraduate Student of Reproduction Biology, ${ }^{2}$ Department of Veterinary Reproduction, Faculty of Veterinary Medicine, \\ Universitas Airlangga, Surabaya, Indonesia, *Corresponding Author: imam.mustofa@,fkh.unair.ac.id
}

(Received December 12, 2017; Accepted February 4, 2018)

\begin{abstract}
The objective of this study was to identify the levels of Blood Urea Nitrogen (BUN) and its relation to the reproductive efficiency and serum progesterone concentration in lactating Holstein Friesian dairy cattle. Data were obtained by stratified random sampling from population to get 18 dairy cows, which divided into three groups. The first, second, and third groups each with milk yield of less than 17, between 17-21, and over 21 liters/day, and with calving interval of less than 365, between 365-450 and more than 450 days. Blood was collected from the coccygeal vein at the time of insemination (D0), 7 day (D+7) and 22 days $(\mathrm{D}+22)$ after insemination. BUN and progesterone concentration were measured. Data analysis showed no significant difference $(\mathrm{P}>0.05)$ on the observed parameters. Data regrouping based on BUN concentration showed that the mean of services per conception $(\mathrm{S} / \mathrm{C})$ was lower and conception rate $(\mathrm{CR})$ was higher $(\mathrm{P}<0.05)$ in dairy cattle having $\mathrm{BUN}<18$ than those of with BUN $>18 \mathrm{mg} / \mathrm{dL}$. The mean of progesterone concentration at $\mathrm{D}+22$ was higher $(\mathrm{P}<0.05)$ than those at $\mathrm{D} 0$ and $\mathrm{D}+7$ in pregnant dairy cows and with $\mathrm{BUN}<18 \mathrm{mg} / \mathrm{dL}$, as well as those at $\mathrm{D}+22$ in non-pregnant dairy cows with $\mathrm{BUN}>18$ and $\mathrm{BUN}<18 \mathrm{mg} / \mathrm{dL}$. This study concluded that high BUN concentration affect the reproductive efficiency of dairy cows by decreasing $\mathrm{CR}$ and increasing progesterone serum concentration.
\end{abstract}

Keywords: Reproductive efficiency, progesterone, BUN, milk yield Available online at http://www.vetmedmosul.org/ijvs

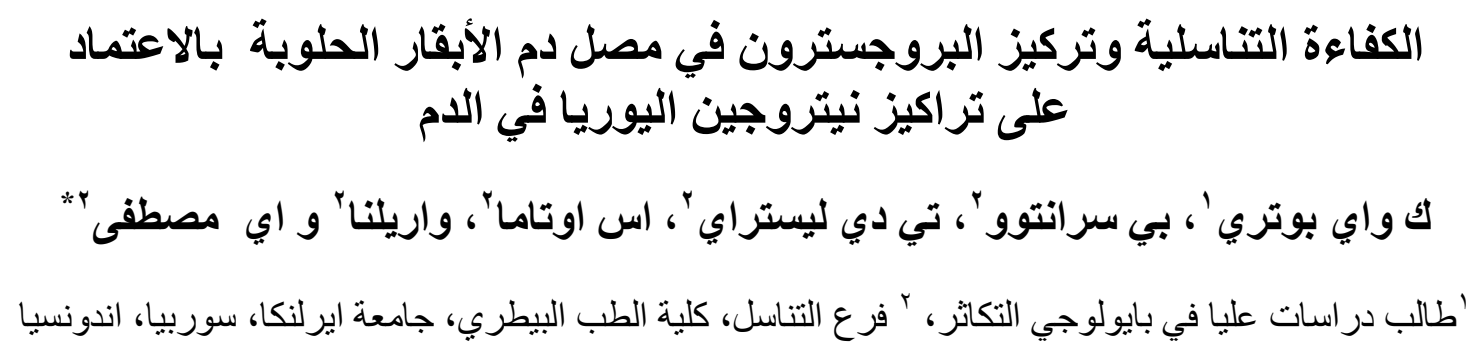

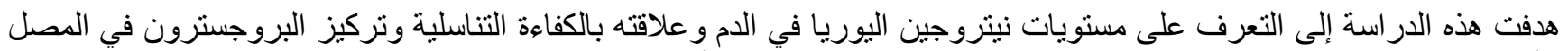

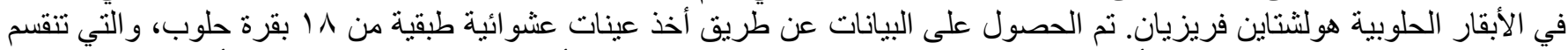

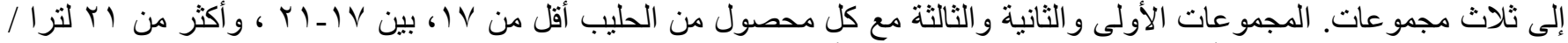

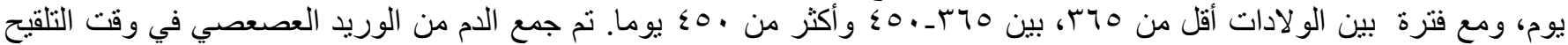

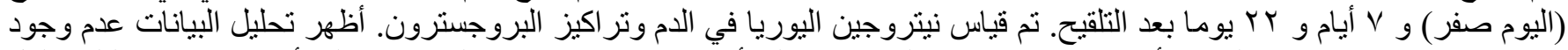

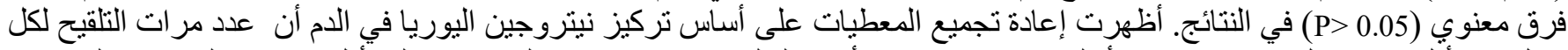

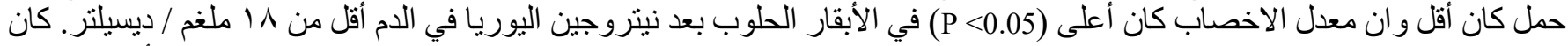

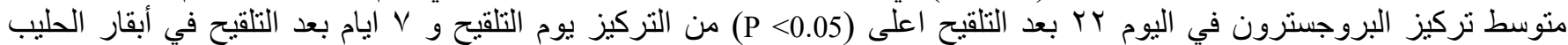

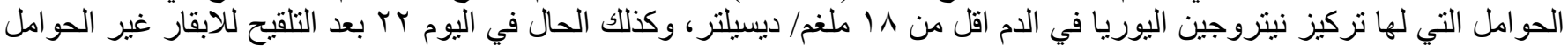




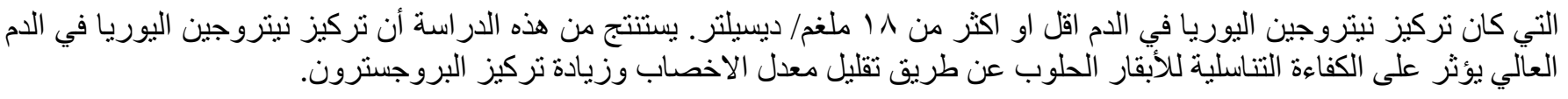

\section{Introduction}

Nutrition management plays an important role in dairy farming. Feeding with high protein content can stimulate high milk production (1). Dairy farmers generally increase the amount of feeding in order increasing milk production, but increasing the amount of feed protein was known to be detrimental to reproductive performance $(2,3)$. The final product of protein metabolism in ruminants is urea which then circulates in the bloodstream (3). There is a positive correlation between BUN and MUN and their concentrations in cattle body tend to be balanced $(5,6)$. Therefore, both MUN and BUN measurements could be utilized as important information for farmers about the nutritional status and health of cattle (3). High BUN concentration indicated an inefficient usage of nitrogen intake for both growth and milk production (7). High feed proteins in dairy cows was reported to be associated with decreased conception rates $(8)$, uterine $\mathrm{pH}(9,10)$, ovarian function and increased services per conception (11). High blood urea delayed the clearance of uterine contamination and decrease immunity, the secretion of $\mathrm{K}, \mathrm{Mg}$, and $\mathrm{P}$ in lactating cows and caused hormonal imbalances $(12,13)$. High concentrations of urea nitrogen in dairy cows causes a negative effect on reproduction because it inhibited follicular development and fertilization, decreased the binding of luteinizing hormone to its receptors on ovaries as well as progesterone binding capacity to ovaries receptor (14).

The aim of this study was to identify the profile of progesterone and Blood Urea Nitrogen (BUN) concentrations and their relation to reproductive efficiency in dairy cows.

\section{Materials and methods}

This study was conducted on dairy cows with a total population about 1000 in small stakeholder farms at Precet Sumbersuko, Wagir, Malang Regency during the period from May 2017 to September 2017. The criteria of dairy cows being studied were non pregnant and in the lactation phase.

\section{Data collection procedures}

The data were collected from 100 non pregnant, lactating dairy cows based on age, parity, BCS (1-9), milk yield and reproduction based on farmers' and inseminator's recording data. On the basis of 50 cows were randomly isolated to conduct a survey on reproductive efficiency and feed given (grass and concentrate). From 50 cows that have been surveyed 18 cows with the criteria of BCS 4-7 (scale 9 ), parity 2 and age \pm 4 years were selected and grouped into three of 6 each based on the quantity of milk yield and reproductive efficiency: First group (KI): dairy cows with milk yield less than 17 liters per day, and calving interval rate less than 365 days, Second group (K2): dairy cows with milk yield 17 to 21 liters per day with Calving Interval 365 up to 450 days, third group (K3): dairy cow with milk yield more than 21 liters per day and calving interval rate more than 450 days. At estrus, cows were artificially inseminated and blood was collected from the coccygeal vein at D0 (time of $\mathrm{AI}$ ), D+7, and $\mathrm{D}+22$. The pregnancy was examined three months after insemination by rectal palpation.

Blood Urea Nitrogen (BUN) was measured by means of Berthelot method using urea nitrogen diagnostic kit (Pointe Scientific, Inc), and expressed as $\mathrm{mg} / \mathrm{dl}$ while progesterone concentration was measured by ELISA test using diagnostic progesterone kit (DRG Diagnostic, Inc).

\section{Data analysis}

The analysis was conducted to identify the homogeneity of sample data with sub-population (50 with 100 dairy cows) based on parameters of age, parity, milk yield, and BCS. Similarly, the homogeneity of sample data between the 18 cows to be further explored with 50 cow samples based on $\mathrm{S} / \mathrm{C}, \mathrm{CI}, \mathrm{DO}$, and feed parameters. Blood Urea Nitrogen $(\mathrm{BUN}), \mathrm{S} / \mathrm{C}$ and $\mathrm{CR}$ values were analyzed to determine the possible differences between groups. Further analysis of milk yield, reproductive efficiency, and feeding factors were performed by regrouping based on BUN concentrations (BUN $\geq 18$ and $\mathrm{BUN}<18 \mathrm{mg} / \mathrm{dl}$ ). Analysis of progesterone concentrations was based on criteria for combination of BUN concentrations (BUN $\geq 18$ and BUN $<18$ ), and pregnancy status (pregnant or non-pregnant). The overall analysis was performed by analysis of variance (ANOVA) of SPSS 20.0 for Windows program at $95 \%$ confidence level.

\section{Results and discussion}

Data obtained from 100 cows taken randomly from the population and the data of 50 cows samples have a suitability, i.e. on the average of age (4.86 and 4.19 years), milk yield (19.78 and 19.26 liters/day), parity (2.35 and 2.32), and BCS (4.92 and 4.88). Mean of BUN concentrations were not significantly different $(\mathrm{P}>0.05)$ among the groups (Table 1). High milk production did not affect BUN concentrations in these cattle. In dairy cows, milk production can be affected by several factors such as 
breed, management, environmental conditions, feed, and lactation phase and health status condition (15). BUN is the end result of nitrogen metabolism in ruminants (7).

The parameter grouping in Table 1 was based on the difference of milk yield and CI, so each of the two parameters was significantly different $(\mathrm{P}<0.05)$. A rhythmic calving interval will have a positive impact on milk production (16), a calving interval of more than 400 days was known to have an effect on increased milk production (17), which was in line with increasing S/C (18). It was probably related to the concentrations of nitrogen urea in the body that also contaminate the cow's uterine fluid thus disrupting conception (13).

Table 1. Milk yield, reproductive efficiency and BUN on experimental groups

\begin{tabular}{lccc}
\hline Parameters & $\mathrm{K} 1$ & $\mathrm{~K} 2$ & $\mathrm{~K} 3$ \\
\hline milk yield (kg/cow/day) & $13.17 \pm 0.83^{\mathrm{a}}$ & $19.17 \pm 0.60^{\mathrm{b}}$ & $27.33 \pm 1.84^{\mathrm{c}}$ \\
CI (days) & $357.33 \pm 1.91^{\mathrm{a}}$ & $409.17 \pm 8.73^{\mathrm{b}}$ & $505.33 \pm 35.61^{\mathrm{c}}$ \\
S/C & $1.33 \pm 0.21^{\mathrm{a}}$ & $3.83 \pm 0.31^{\mathrm{b}}$ & $6.67 \pm 0.33^{\mathrm{c}}$ \\
DO (days) & $66.17 \pm 7.28^{\mathrm{a}}$ & $55.33 \pm 4.85^{\mathrm{a}}$ & $59.50 \pm 8.13^{\mathrm{a}}$ \\
BUN (mg/dl) & $14.92 \pm 1.59^{\mathrm{a}}$ & $16.58 \pm 1.14^{\mathrm{a}}$ & $15.33 \pm 1.52^{\mathrm{a}}$ \\
CR & $33.33 \%$ & $50 \%$ & $33.33 \%$ \\
\hline
\end{tabular}

Different superscripts in one row showed a significant difference $(\mathrm{P}<0.05) ; \mathrm{G}=\mathrm{Groups} ; \mathrm{DO}=$ Days open; $\mathrm{S} / \mathrm{C}=\mathrm{Services}$ per conception; $\mathrm{CI}=$ Calving interval; $\mathrm{BUN}=$ Blood urea nitrogen; $\mathrm{CR}=$ Conception rate; $\mathrm{K} 1=$ milk yield $<17$ liters/day, calving interval $<365$ days; $\mathrm{K} 2=$ milk yield 17-21 liters/day, calving interval 365-450 days; $\mathrm{K} 3=$ milk yield $>21$ liters/day, calving interval $>450$ days; replicates $=6$.

The data of blood urea nitrogen (BUN) and conception rate (CR) obtained on groups in Table 1 did not significantly different $(\mathrm{P}>0.05)$, thus then regrouped based on BUN concentrations (BUN> 18 and $\mathrm{BUN}<18 \mathrm{mg} / \mathrm{dL}$ ), added with feed intake (grass, concentrate, and concentrate to grass ratio) parameters. The result showed that the mean of $\mathrm{S} / \mathrm{C}$ was lower and $\mathrm{CR}$ was higher both significantly $(\mathrm{P}<0.05)$ in dairy cattle having BUN $<18$ than those of with BUN $>18 \mathrm{mg} / \mathrm{dL}$ (Table 2).

Table 2. Milk yield, reproductive efficiency and feed based on BUN content

\begin{tabular}{|c|c|c|}
\hline Parameters & $\begin{array}{c}\mathrm{BUN}<18 \\
\mathrm{mg} / \mathrm{dL}\end{array}$ & $\begin{array}{c}\mathrm{BUN}>18 \\
\mathrm{mg} / \mathrm{dL}\end{array}$ \\
\hline BUN (mg/dL) & $13.67 \pm 0.61^{\mathrm{a}}$ & $19.50 \pm 0.52^{\mathrm{b}}$ \\
\hline milk yield (liter/day) & $18.75 \pm 2.08^{\mathrm{a}}$ & $22.17 \pm 2.02^{\mathrm{b}}$ \\
\hline \multicolumn{3}{|l|}{ Reproductive efficiency } \\
\hline $\mathrm{S} / \mathrm{C}$ & $3.50 \pm 0.69^{\mathrm{a}}$ & $4.83 \pm 0.87^{b}$ \\
\hline $\mathrm{CR}$ & $58.33 \%{ }^{\mathrm{a}}$ & $? ? ? ? 0 \% \mathrm{~b}$ \\
\hline DO (days) & $62.17 \pm 5.62^{\mathrm{a}}$ & $56.67 \pm 3.44^{\mathrm{a}}$ \\
\hline CI (days) & $424.00 \pm 26.68^{\mathrm{a}}$ & $423.83 \pm 21.90^{\mathrm{a}}$ \\
\hline \multicolumn{3}{|c|}{ 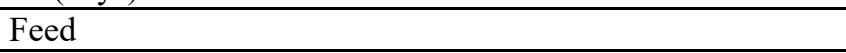 } \\
\hline Concentrate (C) kg/cow/day & $10.5 \pm 2.95^{\mathrm{a}}$ & $10.33 \pm 0.47^{\mathrm{a}}$ \\
\hline Grass $(\mathrm{G}) \mathrm{kg} /$ cow/day & $33.33 \pm 4.24^{\mathrm{a}}$ & $35 \pm 2.31^{\mathrm{a}}$ \\
\hline $\mathrm{C} / \mathrm{G}$ & $32.42 \pm 3.36 \%{ }^{\mathrm{a}}$ & $29.52 \pm 0.95 \%{ }^{\mathrm{a}}$ \\
\hline \multicolumn{3}{|c|}{$\begin{array}{l}\text { Different superscripts in a row showed significant } \\
\text { differences }(\mathrm{P}<0.05) ; \mathrm{BUN}=\mathrm{Blood} \text { Urea Nitrogen; } \mathrm{S} / \mathrm{C}= \\
\text { Services per conception; } \mathrm{CR}=\mathrm{Conception} \text { rate; } \mathrm{DO}=\mathrm{Days} \\
\text { open; } \mathrm{CI}=\text { Calving interval; } \mathrm{C} / \mathrm{G}=\text { concentrate to grass } \\
\text { ratio. }\end{array}$} \\
\hline
\end{tabular}

Urea nitrogen in cow body fluids largely derives from a high protein intake of feed; the addition of concentrate in dairy feed will affect the quality and composition of milk (19). Increased feeding of high rumen degradable protein in dairy cows through the addition of concentrates potentially increases milk production by increasing protein synthesis in rumen (20). In this study the $\mathrm{C} / \mathrm{G}$ values were not significantly different $(\mathrm{P}>0.05)$, whereas $\mathrm{BUN}$ was significantly different $(\mathrm{P}<0.05) \quad($ Table 2$)$, indicating inefficient metabolism of protein in dairy cows with high BUN. High BUN concentrations indicate an inefficient utilization of nitrogen intake in the body for both growth milk productions (7). High plasma or milk urea indicates a high rumen ammonia concentrations. Excess ammonia will diffuse to the bloodstream and converted to urea in the liver (20). Feed with high protein content will result in high concentrations of urea nitrogen in plasma and milk (21). Higher concentrations of urea nitrogen in cows with lower concentrate intake indicate a lack of synchronization between energy and protein in the rumen (20). Feed consumption with a high content of rumen degradable protein in dairy cows is closely related to increased BUN concentrations $(5,22)$ and decreased pregnancy rates $(10)$.

Higher milk production was accompanied with higher BUN concentrations (Table 2). BUN concentrations are one of the renal function evaluation criteria that reflect glomerular filtration rate (23). High BUN concentrations indicate an imbalance of nitrogen metabolism. High intake of protein intended to increase milk production and leaves a higher rumen undegradable protein that ends up as BUN and MUN. However, different milk yields obtained from cows fed the same quality and quantity of feed (Table 2) 
can be caused by genetic factors. There are potential genetic markers and genes for the production characteristic in dairy cows, i.e. AA, AG, and GG. Cattle with AA genotype have higher milk yields than cows with GA or GG genotype (24). The genotypes AA, AG, and GG have the frequency of $0.07,0.34$, and 0.59 , respectively, in the livestock population (25). In addition to genetic factors, prolactin (PRL) concentrations in the circulatory system are positively correlated with photoperiodic (26), but in this study the photoperiodic of all cows was the same.

\section{BUN concentrations and reproductive efficiency}

The reproductive efficiency of dairy cows in the tropical area is relatively low with more repeat breeder cases (27) and the average of first artificial insemination after parturition is longer (28) than dairy cows in sub-tropical regions. In addition, BUN concentrations above $18 \mathrm{mg} / \mathrm{dL}$ may decrease uterine $\mathrm{pH}$ and decrease fertility in dairy cows (12), by affecting the motility and viability of sperm in female reproductive tract so as to decrease pregnancy rate. The occurrence of repeat breeding in dairy cows may also be due to oocyte disorders (29).

In this study the reproductive efficiency based on CR and $\mathrm{S} / \mathrm{C}$ was better $(\mathrm{P}<0.05)$ in the $\mathrm{BUN}<18 \mathrm{mg} / \mathrm{dL}$ group compared with BUN $>18 \mathrm{mg} / \mathrm{dL}$ group, but the DO and CI were relatively equal $(\mathrm{P}>0.05)$ (Table 2$)$. Dairy cows that have higher BUN concentrations have higher milk production, higher $\mathrm{S} / \mathrm{C}$ and lower $\mathrm{CR}(\mathrm{p}<0.05)$, whereas DO and CI were both equal ( $P>0.05)$. This fact indicates that BUN concentrations exceeding the threshold of 18 $\mathrm{mg} / \mathrm{dL}$ interfere with reproduction at the time of fertilization. The normal range of nitrogen urea concentrations in cows is 8 to $25 \mathrm{mg} / \mathrm{dL}$ (21). Several previous studies had shown that concentrations of nitrogen urea in cows greater than $18 \mathrm{mg} / \mathrm{dL}$ may cause some negative effects on reproduction, decreased pregnancy rate (12), increasing $\mathrm{S} / \mathrm{C}$, decreasing uterine $\mathrm{pH}$ and affecting the balance of reproductive hormone concentrations $(2,14)$.

Many factors can affect $\mathrm{CR}$ in lactating cows including metabolic factors, infectious diseases and environmental conditions. Metabolism in cows with high milk production causes a lower $\mathrm{CR}$ value. This may be associated with lower body condition score in cows with high milk production (18). The decrease in CR value may also be associated with an increase in protein feed (30). This is in line with previous studies suggested that BUN concentrations above $19 \mathrm{mg} / \mathrm{dL}$ will decrease uterine $\mathrm{pH}$ and decrease the fertility of dairy cows (31). High rumen degradable protein content in cow will cause urea concentrations in blood, milk and urine to increase which causes fertility problems, decreased energy availability, environmental pollution and economic losses (32).

High concentrations of urea nitrogen in body fluids can decrease pregnancy rates (12), ammonia concentrations will increase so as to delay the clearance of uterine contamination and decrease the functioning of the immune system, decrease the secretion of $\mathrm{K}, \mathrm{Mg}$, and $\mathrm{P}$ in lactating cows and cause hormonal imbalance by decreasing binding luteinizing hormone to the ovary receptors $(8,14)$. Progesterone is an essential hormone in the entire process of cow reproduction from ovulation to maintaining pregnancy, development of the mammary glands and the associated neurobehavioral role of sexual response (33).

\section{Serum progesterone concentrations}

Progesterone is produced by the corpus luteum in the ovaries controlled by the prolactin (PRL). Progesterone concentrations in the circulation are fluctuating following the estrous cycle, low in the follicular phase and high in the luteal phase. In dairy cows that heat and then inseminated and pregnant, the originally low concentration of progesterone in the blood will rise and remain high until the parturition. In cows that were not fertilized after insemination, the endometrium will produce prostaglandin (PG) F2 $\alpha$ starting around day 14. The PGF2 $\alpha$ serves to regress the corpus luteum, so that the corpus luteum begins to degenerate on day 17 , followed by a drop in progesterone to basal concentrations on days 20 to 23 as estrus return (34). Thus the physiological concentrations of progesterone in serum differed between pregnant and non-pregnant cows. Therefore, the progesterone concentration in this study was regrouped based on BUN concentrations then divided again in pregnant and non-pregnant cows (Fig. 1).

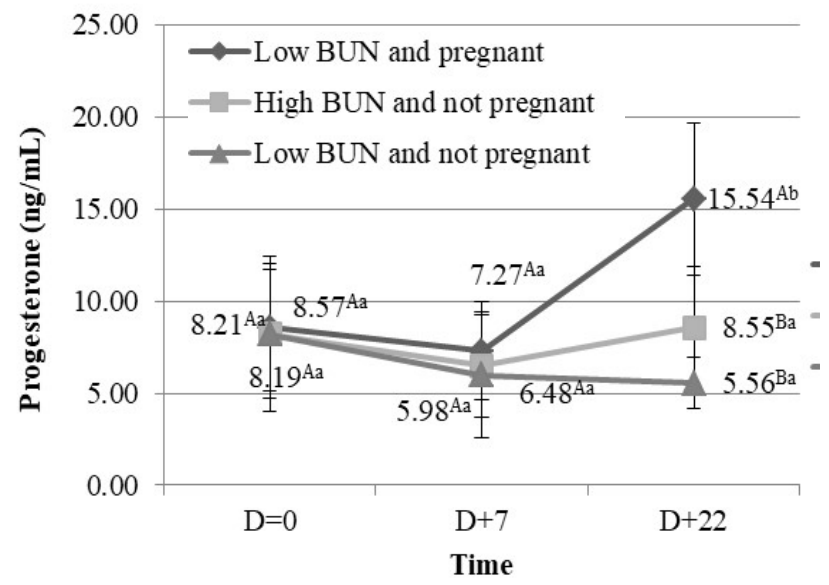

Figure 1. Serum progesterone concentration of cow group with low BUN and pregnant.

High BUN and not pregnant, also low BUN and not pregnant at $\mathrm{AI}(\mathrm{D} 0), 7^{\text {th }}$ day $(\mathrm{D}+7)$, and $22^{\text {nd }}(\mathrm{D}+22)$ after AI. Description: The letters A and B are significantly different $(\mathrm{P}<0.05)$ between treatments, $\mathrm{a}$ and $\mathrm{b}$ are significantly different $(\mathrm{P}<0.05)$ between sampling days. 
In this study, the progesterone $\mathrm{D}+22$ in the cows that were non pregnant with high BUN or low BUN concentration were not differ significantly. There was a similar pattern on progesterone concentrations D0, D+7, and $\mathrm{D}+22$ in non-pregnant cow with high BUN concentration and pregnant cow with low BUN concentration. However D+22 serum progesterone concentrations in non-pregnant cow with $\mathrm{BUN}>18 \mathrm{mg} / \mathrm{dL}$ were lower than serum progesterone $\mathrm{D}+22$ in pregnant dairy cow with BUN $<18 \mathrm{mg} / \mathrm{dL}$. This was in accordance with previous reports $(1,13,14)$ stated that high concentrations of BUN may decrease progesterone concentration in dairy cows. Feed intake and high milk production have been associated with increased portal blood flow, and increased progesterone clearance by the liver (35). Low concentrations of progesterone at the beginning of luteal phase negatively affect the survival of the embryo (36). This could be the cause of the failure of pregnancy in cows with high BUN (Figure 1). Progesterone is produced by the corpus luteum in the ovaries that is controlled by the prolactin hormone, while the prolactin hormone as discussed previously also plays a role in milk production in response to nutrient intake. The molecular mechanisms of BUN effects on serum progesterone concentrations are unknown, therefore it needs for further researches involves measurements of hormone concentrations of PRL and associated molecules.

\section{Acknowledgment}

We would like to thanks to Drh. Dikko Yudha Hidayat and Drh. Nowo Siswo Yuworo, M.Si., who has been pleased to provide survey access and sampling of this study.

\section{References}

1. Nourozi M, Moussavi AH, Abazari H, Zadeh MR. Milk urea nitrogen and fertility in dairy farms. J Anim Vet Adv. 2010;10:1519-1525.

2. Roelofs JB, Eerdenburg V, Soede NM, Kemp B. Various behavioral signs of estrous and their relationship with time of ovulation in dairy cattle. Theriogenol. 2005;13:66-77.

3. Biswajit R, Brahhma B, Ghsh S, Pankaj PK, Manda G. Evaluation of milk urea concentration as useful indicator for dairy herd management: a review. Asian J Anim Vet. 2011;6:1-9.

4. Butler WR. Relationships of dietary protein and fertility. J. Dairy Techo. 2005;17:159-168.

5. Hammon DS, Holyoak GR, Dhiman TR. Association between blood plasma urea nitrogen levels and reproductive fluid urea nitrogen and ammonia concentrations in early lactation dairy cows. Anim Reprod Sci. 2005;86:195-204.

6. Fallahnezhad AN, Moghaddam GA. The relationships between milk production and some blood metabolites and their effects on returning to estrus in lactating holstein dairy cows. Iranian J Rumin Health Res. 2016;2:35-45.

7. Gulinski PE, Salamonczyk, Młynek K. Improving nitrogen use efficiency of dairy cows in relation to urea in milk - a review. J Anim Sci. 2016;34:5-24.
8. Guo K, Russek-Cohen E, Vaner MA, Kohn RA. Effect of milk urea nitrogen and other factor on probability of conception of dairy cows. J Dairy Sci. 2004;87:188-1885.

9. Butler WR. Nutritional interactions with reproductive performance in dairy cattle. Anim Reprod Sci. 2000;60:449-457.

10. Islam MR, Uddin MN, Akanda MR, Khan MMH, Baset MA, Belal SA. Effect of milk urea nitrogen of dairy cows in relation to breed. Iranian J Applied Anim Sci. 2015;2:279-283.

11. Jackson RA, Wills JR, Kendall NR, Green MJ, Murray RD, Dobson $\mathrm{H}$. energy metabolites in pre- and post partum dairy cattle as predictor of reproductive disorders. Vet Rec. 2011;1:168-262.

12. Rajala-Schultz PJ, Saville WJA, Frazer GS, Wittum TE. Association between milk urea nitrogen and fertility in ohaio dairy cows. J Dairy Sci. 2001;84:482-489.

13. Walsh SW, Williams EJ, Evans ACO. A review of the causes of poor fertility in high milk producing dairy cows. J. Anim Reprod Sci. 2011;1:127-138

14. Arunvipas, P. Determining relationship between milk urea nitrogen, feeding management, reproduction and environmental indicator in commercial dairy herds. [Master's Thesis] Canada: University of Prince Edward Island; 2004;pp:205.

15. N.R.C. Nutrient Requirement of Dairy Cattle. 10th Ed. National Academy Press. Washington. USA. 2001.

16. Baul S, Cziszter LT, Acatincai S, Cismas T, Erina S, Gavojdian D, Tripon I, Buzamat G. Effect of calving interval on milk yield and quality evolution during lactation in dairy cows. Anim Sci Biotech. 2013;1:289-293.

17. Popescu A. research on the influence of the calving interval on milk yield. Scientific Papers Series Management Economic Engineering in Agriculture and Rural Development. 2014;14:291-296.

18. Ferguson JD, Skidmore A. Reproductive performance in a select sample of dairy herds. J Dairy Sci. 2013;96:1269-1289.

19. Horký P. Effect of protein concentrate supplement on the qualitative and quantitative parameters of milk from dairy cows in organic farming. Anim Sci. 2014;142:341-352.

20. Schobitz J, Albarran MR, Balocchi OA, Wittwer F, Noro M, Pulido RG. Effect of Increasing Pasture Allowance and Concentrate Supplementation on Animal Performance and Microbial Protein Synthesis in Dairy Cows. Arch Med Vet. 2013;45:247-258.

21. Rukkwamsuk T. Effect of nutrition on reproductive performance of postparturient dairy cows in the tropics : a review. Thai J Vet Med Suppl. 2011;41:103-107.

22. Godden SM, Lissemore KD, Kelton DF, Leslie KE, Walton JS, Lumsden JH. Relationships between milk urea concentrations and nutritional management, production, and economic variables in Ontario dairy herds. J Dairy Sci. 2001;84:1128-1139.

23. Murayama I, Miyano A, Sasaki Y, Kimura A, Sato S, Furuhama K. Glomerular filtration rate in Holstein dairy cows estimated from a single blood sample using iodixanol. J Dairy Sci. 2013;96:5120-5138.

24. Dong $\mathrm{CH}$, Song XM, Zhang L, Jiang JF, Zhou JP, JiangYQ. New insights into the prolactin-RsaI (PRL-RsaI) locus in Chinese Holstein cows and its effect on milk performance traits. Genet Mol Res. 2013;12:5766-5773.

25. Sonmez $\mathrm{Z}$ and $\mathrm{M}$. Ozdemir. Prolactin-RsaI gene polymorphism in East Anatolian Red cattle in Turkey. S Afr J Anim Sci. 2017;47:124129.

26. Crawford HM, Morin DE, Wall EH, McFadden TB, Dahl GE. Evidence for a role of prolactin in mediating effects of photoperiod during the dry period. Animals 2015;5:803-820.

27. Yusuf M, Rahim L, Asja MA, Wahyudi A. The incidence of repeat breeding in dairy cows under tropical condition. Media Peternakan. 2012;4:28-31.

28. Yusuf M, Toleng AL, Syafar MF. Distribution of cows by days in milk (DIM) at first AI and calving to conception interval in dairy cows. Media Peternakan. 2012;12:185-189.

29. Gunn PJ, Schoonmaker JP, Lemenager RP, Bridges GA. Feeding excess crude protein to gestating and lactating beef heifers: impact on 
parturition, milk composition, ovarian function, reproductive efficiency and pre-weaning progeny growth. Livestock Sci. 2014; $167: 435-448$.

30. Ferreira G. Reproductive performance of dairy farms in western Buenos Aires province, Argentina. J Dairy Sci. 2013;96:8075-8080.

31. Amundson OL, Larimore EL, McNeel AK, Chase Jr CC, Cushman RA, Freetly HC, Perry GA. Uterine environment and pregnancy rate of heifers with high blood urea concentrations. J Anim Reprod Sci. 2016;173:56-62.

32. Widyobroto BP, Rochijan, Ismaya, Adiarto, Suranindyah YY. The Impact of balanced energy and protein supplementation to milk production and quality in early lactating dairy cows. J Indonesian Trop Anim Agric. 2016;41:83-90.
33. Malekinejad H, Rezabakhsh A. hormones in dairy foods and their impact on public health- a narrative review article. Iran J Public Health. 2015;44:742-758.

34. O'Connor ML. Milk progesterone analysis for determining reproductive status. PennState Extension. 2015.

35. Blavy P, Derks M, Martin O, Höglund JK, Friggens NC. Overview of progesterone profiles in dairy cows. Theriogenol. 2016;86:1061-1071.

36. Martin O, Friggens NC, Dupont J, Salvetti P, Freret S, Rame C, Gatien J. Data-derived reference profiles with corepresentation of progesterone, estradiol, LH and FSH dynamics during the bovine estrous cycle. Theriogenol. 2013;79:31-43. 